\title{
Phase behavior of heavy oil-solvent mixture systems under reservoir conditions
}

\author{
Xiao-Fei Sun ${ }^{1} \cdot$ Zhao-Yao Song $^{2} \cdot$ Lin-Feng Cai $^{1} \cdot$ Yan-Yu Zhang ${ }^{1} \cdot$ Peng Li ${ }^{1}$
}

Received: 13 August 2019 / Published online: 14 May 2020

(c) The Author(s) 2020

\begin{abstract}
A novel experimental procedure was proposed to investigate the phase behavior of a solvent mixture (SM) $\left(64 \mathrm{~mol} \% \mathrm{CH}_{4}\right.$, $8 \mathrm{~mol} \% \mathrm{CO}_{2}$, and $28 \mathrm{~mol} \% \mathrm{C}_{3} \mathrm{H}_{8}$ ) with heavy oil. Then, a theoretical methodology was employed to estimate the phase behavior of the heavy oil-solvent mixture (HO-SM) systems with various mole fractions of SM. The experimental results show that as the mole fraction of SM increases, the saturation pressures and swelling factors of the HO-SM systems considerably increase, and the viscosities and densities of the HO-SM systems decrease. The heavy oil is upgraded in situ via asphaltene precipitation and SM dissolution. Therefore, the solvent-enriched oil phase at the top layer of reservoirs can easily be produced from the reservoir. The aforementioned results indicate that the SM has promising application potential for enhanced heavy oil recovery via solvent-based processes. The theoretical methodology can accurately predict the saturation pressures, swelling factors, and densities of HO-SM systems with various mole fractions of SM, with average error percentages of $1.77 \%$ for saturation pressures, $0.07 \%$ for swelling factors, and $0.07 \%$ for densities.
\end{abstract}

Keywords Heavy oil · Solvent mixture $\cdot$ PR-EOS $\cdot$ Phase behavior $\cdot$ Pressure-volume-temperature (PVT)

\section{Introduction}

The observed performance from many heavy oil reservoirs in Canada, China, and Venezuela, such as the Orinoco Oil Belt, Lindbergh, and Tuha Fields, has been significantly better than that from conventional heavy oil reservoirs during primary production processes (Abusahmin et al. 2017; Guan et al. 2008; Maini 1999; Sun et al. 2017a, 2019a, b; Zhou et al. 2016). One of the possible reasons for this difference is the in situ foamy oil occurrence (the solution gas is trapped in the oil phase as dispersed bubbles) (Du et al. 2016; Liu et al. 2017; Sun et al. 2014, 2018a; Zhang et al. 2015; Zhou et al. 2017). However, the gas bubbles eventually become a continuous free gas due to low reservoir pressure. Therefore,

Edited by Yan-Hua Sun

Xiao-Fei Sun

sunxiaofei540361@163.com

1 School of Petroleum Engineering, China University of Petroleum (East China), Qingdao 266580, Shandong, People's Republic of China

2 Nanjing Air Fuel Co., Ltd., Nanjing 211113, Jiangsu, People's Republic of China the foamy oil phenomenon disappears after primary production, resulting in low ultimate oil recovery factors $(5 \%-15 \%)$ in heavy oil reservoirs (Shokri and Babadagli 2017; Soh et al. 2018).

Extensive studies have been performed to investigate the potential of solvent-based processes for heavy oil recovery after primary production. The recently examined solventbased processes include vapor extraction (Kordestany et al. 2019; Talbi et al. 2008; Upreti et al. 2007), cyclic solvent injection (CSI) (Du et al. 2017; Sun et al. 2015; You et al. 2019), and solvent flooding (Luo et al. 2012, Zhang et al. 2019a). Generally, solvents (e.g., $\mathrm{CO}_{2}, \mathrm{CH}_{4}$, and $\mathrm{C}_{3} \mathrm{H}_{8}$ ) are used in a pure or mixed form during the aforementioned processes. The beneficial mechanisms of solvent-based processes mainly include enhanced oil swelling and oil mobility improvement, as well as reductions in interfacial tension (IFT), oil viscosity and density (Dong et al. 2013; Haddadnia et al. 2018a, b; Liu 2019; Yu and Shen 2008; Zhang et al. 2019b). All of these mechanisms can be determined by phase behavior data ( $\mathrm{Li}$ et al. 2011, 2012a, 2013). Thus, obtaining accurate phase behavior data is vital in analyses of solvent-based processes.

The phase behavior of various solvents with heavy oil has been systematically investigated in previous 
studies. Frauenfeld et al. (2002) measured the viscosities of $\mathrm{CH}_{4}, \mathrm{CO}_{2}$, and $\mathrm{C}_{3} \mathrm{H}_{8}$ in Lloydminster heavy oil (LHO) at $292.15 \mathrm{~K}$ and several pressures. Luo et al. (2007a) measured the viscosities and swelling factors of different $\mathrm{LHO}-\mathrm{C}_{3} \mathrm{H}_{8}$ systems at pressures from 200 to $800 \mathrm{kPa}$. Badamchi-Zadeh et al. (2009) investigated the saturation pressures, liquid phase densities and viscosities of $\mathrm{C}_{3} \mathrm{H}_{8}$-Athabasca bitumen systems for temperatures from 283.15 to $323.15 \mathrm{~K}$. Li et al. (2011) measured the swelling factors, saturation pressures, and viscosities of heavy oilthree solvent $\left(\mathrm{C}_{3} \mathrm{H}_{8}, \mathrm{CO}_{2}-\mathrm{C}_{3} \mathrm{H}_{8}\right.$, and $\left.\mathrm{CO}_{2}-n-\mathrm{C}_{4} \mathrm{H}_{10}\right)$ systems at temperatures from 280.45 to $391.55 \mathrm{~K}$.

A comprehensive experimental study of solvent and bitumen/heavy oil systems can be found in recent publications by SHARP research group at University of Calgary (Azinfar et al. 2018a, b; Haddadnia et al. 2018a, b; Nourozieh et al. 2014; Zirrahi et al. 2014, 2017a, b). Zirrahi et al. (2014) measured the solubility of $\mathrm{CH}_{4}, \mathrm{C}_{2} \mathrm{H}_{6}$, and $\mathrm{CO}_{2}$ in bitumen. Nourozieh et al. (2014) measured the densities of bitumen-pentane mixtures at temperatures varying from ambient up to $200{ }^{\circ} \mathrm{C}$ and at pressures up to $10 \mathrm{MPa}$. Zirrahi et al. (2017a, b) and Azinfar et al. (2018a, b) measured the phase behavior data including solubilities, densities, and viscosities of propane-bitumen (heavy oil) systems in wide ranges of temperature and pressure (including four temperatures of $50,100,150$, and $186^{\circ} \mathrm{C}$, and pressures up to $8.1 \mathrm{MPa}$ ). Haddadnia et al. (2018a) and Azinfar et al. (2018a, b) reported the viscosity and solubility data of butane-Athabasca bitumen (up to $260{ }^{\circ} \mathrm{C}$ ). In addition, they also investigated the thermos-physical properties of $n$-pentane-bitumen systems and $n$-hexane-bitumen systems at different temperatures $\left(30-190{ }^{\circ} \mathrm{C}\right)$, pressures (2-8 MPa), and solvent mass fractions $(0.05-0.5)$ (Haddadnia et al. 2018b).

Based on the aforementioned phase behavior data, many models were developed to predict thermos-physical properties of various solvents (such as $\mathrm{CH}_{4}, \mathrm{C}_{2} \mathrm{H}_{6}, \mathrm{CO}_{2}, \mathrm{C}_{3} \mathrm{H}_{8}$, and so on) in bitumen (heavy oil). The $\mathrm{PR}$ cubic equation of states (EOS) and Krichevsky-Ilinskaya equation were used in those models (Haddadnia et al. 2018b; Zirrahi et al. 2014). Recently, there are some studies that have developed reliable correlations or models for predicting thermos-physical properties of solvent-heavy oil (bitumen) systems by artificial intelligence. For example, Ahmadi et al. (2018) developed a predictive model based on the least-squares support vector machine (LS-SVM) to calculate the $\mathrm{CO}_{2}$ and heavy oil swelling factor and found that the LS-SVM is a straightforward and accurate method to determine the oil swelling factor with negligible uncertainty. Al-Gawfi et al. (2019) developed three generalized correlations using symbolic regression based on genetic programming to predict the solubility, density, and viscosity of light hydrocarbon $\left(\mathrm{C}_{1}\right.$ to $\mathrm{C}_{5}$ ) and bitumen mixtures.
There are a limited number of studies on the phase behavior of heavy oil-solvent mixture (HO-SM) systems. Li et al. (2013) experimentally determined the swelling factors of LHO- $\mathrm{C}_{3} \mathrm{H}_{8}-n-\mathrm{C}_{4} \mathrm{H}_{10}$ systems with different solvent mole fractions at high temperatures and pressures. Yang et al. (2014) determined the saturation pressures and swelling factors of LHO- $-\mathrm{CH}_{4}-\mathrm{C}_{3} \mathrm{H}_{8}$ systems using the PVT tests and a PR-EOS model, respectively. Li et al. (2013) proposed a generalized methodology to predict the swelling factors of LHO- $\mathrm{CO}_{2}-\mathrm{C}_{3} \mathrm{H}_{8}$ and LHO- $\mathrm{CO}_{2}-n-\mathrm{C}_{4} \mathrm{H}_{10}$ systems under reservoir conditions. Yamchi et al. (2018) added propane to the mixtures of butane-bitumen systems and determined the changes in thermos-physical properties. The results showed that the addition of propane resulted in lighter extracted phase and an increase in the saturation pressure of solution. Zhao et al. (2019) measured the saturation pressures of three $\mathrm{HO}-\mathrm{SM}\left(\mathrm{CH}_{4} \mathrm{CO}_{2}, \mathrm{CH}_{4}-\mathrm{C}_{3} \mathrm{H}_{8}\right.$, and $\left.\mathrm{CO}_{2}-\mathrm{C}_{3} \mathrm{H}_{8}\right)$ systems by constant composition expansion tests.

According to the aforementioned studies in the literature, large quantities of phase behavior data are available for various solvents and LHO/bitumen (Athabasca and Cold Lake). However, many heavy oil reservoirs, such as these in the Orinoco Oil Belt, Venezuela, have higher reservoir pressures $(8650 \mathrm{kPa})$ than that in Canada $(1800-2400 \mathrm{kPa})$. The solvents or solvent mixtures for LHO and Athabasca and Cold Lake bitumen investigated in the literature are not suitable for those heavy oil reservoirs with high pressures. Therefore, it is crucial for find an effective injection solvent mixture for solvent-based processes that is applicable to heavy oils with higher pressures.

Compared with commonly used $\mathrm{CO}_{2}$ and $\mathrm{CH}_{4}, \mathrm{C}_{3} \mathrm{H}_{8}$ has higher solubility in heavy oil. Therefore, the addition of $\mathrm{C}_{3} \mathrm{H}_{8}$ increases the contribution of the solvent mixture (SM) to increased oil swelling and reductions in oil viscosity and IFT (Ahadi and Torabi 2018). However, due to the relatively low dew point pressure of $\mathrm{C}_{3} \mathrm{H}_{8}, \mathrm{C}_{3} \mathrm{H}_{8}$ is easily liquefied in the high-pressure reservoir conditions, resulting in larger solvent consumption (Fig. 1).

Therefore, the addition of produced gas (generally, the main components are $\mathrm{CO}_{2}$ and $\mathrm{CH}_{4}$ ) as a carrier gas allows the $\mathrm{SM}$ to be gas phase under reservoir conditions, thereby avoiding the $\mathrm{C}_{3} \mathrm{H}_{8}$ liquefaction and reducing the $\mathrm{C}_{3} \mathrm{H}_{8}$ consumption. In addition, produced gas can be obtained from the primary production of heavy oil reservoirs, and its use improves the availability and economic efficiency of solventbased processes. Therefore, the $\mathrm{SM}\left(\mathrm{CH}_{4}, \mathrm{CO}_{2}\right.$, and $\left.\mathrm{C}_{3} \mathrm{H}_{8}\right)$ can fully utilize the advantages of $\mathrm{C}_{3} \mathrm{H}_{8}$ and produced gas, which have significant potential in heavy oil reservoirs after primary production.

To the best of our knowledge, the phase behavior of $\mathrm{HO}-\mathrm{SM}$ systems $\left(\mathrm{CH}_{4}, \mathrm{CO}_{2}\right.$, and $\left.\mathrm{C}_{3} \mathrm{H}_{8}\right)$ has not yet been investigated although it is crucial for revealing the mechanisms of the SM and designing effective solvent-based 


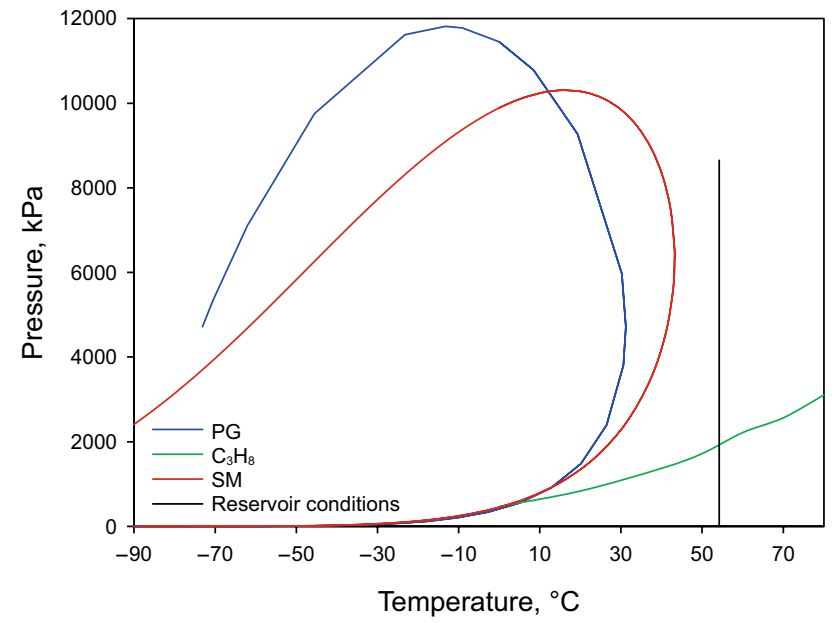

Fig. $1 P-T$ diagrams and reservoir conditions for different solvent types

Table 1 SARA analysis of the VHO sample

\begin{tabular}{llll}
\hline Saturates, wt $\%$ & Aromatics, wt $\%$ & Resins, wt $\%$ & Asphaltenes, wt $\%$ \\
\hline 19.8 & 51.2 & 18.9 & 8.8 \\
\hline
\end{tabular}

processes. It is still lack of basic experimental data for phase behavior of $\mathrm{HO}$ and $\mathrm{SM}\left(\mathrm{CH}_{4}, \mathrm{CO}_{2}\right.$, and $\left.\mathrm{C}_{3} \mathrm{H}_{8}\right)$ systems. In addition, the theoretical methodology is still not available to estimate the phase behavior of HO-SM systems. In this paper, a novel experimental procedure is proposed to investigate the phase behavior of HO-SM systems. First, the saturation pressures, swelling factors, viscosities, and densities of the systems with various mole fractions of SM ranging from 10.29 to $33.54 \mathrm{~mol} \%$ were measured using PVT tests. Then, quantitative analyses were performed to characterize the HO-SM systems at different layers in the PVT cell by measuring the viscosities and densities at different saturation pressures. Finally, a theoretical methodology was proposed to predict the theoretical phase behavior of the HO-SM systems with various mole fractions of SM.

\section{Experimental section}

\subsection{Experimental materials}

A heavy oil (HO) sample from the Orinoco Oil Belt, Venezuela (VHO), was used in this study. The physical properties of the VHO sample are presented in Tables 1 and 2, and the compositional analysis results obtained by the Schlumberger Venezuela are shown in Table 3.

The densities of the HO sample were obtained at experimental pressures from 100 to $10,000 \mathrm{kPa}$ and
Table 2 VHO sample properties

\begin{tabular}{ll}
\hline Physical properties & Values \\
\hline Initial gas-oil ratio, $\mathrm{m}^{3} / \mathrm{m}^{3}$ & 15 \\
Formation volume factor at saturation pressure, $\mathrm{m}^{3} / \mathrm{m}^{3}$ & 1.173 \\
Bubble point pressure, $\mathrm{MPa}$ & 4.95 \\
Acid number, $\mathrm{mg} / \mathrm{g}$ & 4.95 \\
Base number, $\mathrm{mg} / \mathrm{g}$ & 13.57 \\
\hline
\end{tabular}

Table 3 Compositional analysis results of the VHO sample (in mol\%)

\begin{tabular}{|c|c|c|c|}
\hline Components & Reservoir oil & Produced gas & Produced oil \\
\hline $\mathrm{N}_{2}$ & 0.13 & 0.52 & 0.00 \\
\hline $\mathrm{CO}_{2}$ & 2.80 & 10.82 & 0.00 \\
\hline $\mathrm{C}_{1}$ & 22.43 & 86.72 & 0.00 \\
\hline $\mathrm{C}_{2}$ & 0.08 & 0.31 & 0.00 \\
\hline $\mathrm{C}_{3}$ & 0.04 & 0.17 & 0.00 \\
\hline $\mathrm{C}_{4}$ & 0.04 & 0.15 & 0.00 \\
\hline $\mathrm{C}_{5}$ & 0.12 & 0.13 & 0.12 \\
\hline $\mathrm{C}_{6}$ & 0.49 & 1.05 & 0.29 \\
\hline $\mathrm{C}_{7}$ & 0.25 & 0.09 & 0.30 \\
\hline $\mathrm{C}_{8}$ & 0.32 & 0.03 & 0.42 \\
\hline $\mathrm{C}_{9}$ & 0.50 & 0.01 & 0.67 \\
\hline $\mathrm{C}_{10}$ & 0.90 & 0.00 & 1.21 \\
\hline $\mathrm{C}_{11}$ & 1.53 & 0.00 & 2.06 \\
\hline $\mathrm{C}_{12}$ & 1.84 & 0.00 & 2.48 \\
\hline $\mathrm{C}_{13}$ & 1.96 & 0.00 & 2.65 \\
\hline $\mathrm{C}_{14}$ & 2.13 & 0.00 & 2.87 \\
\hline $\mathrm{C}_{15}$ & 2.24 & 0.00 & 3.02 \\
\hline $\mathrm{C}_{16}$ & 2.38 & 0.00 & 3.21 \\
\hline $\mathrm{C}_{17}$ & 2.39 & 0.00 & 3.22 \\
\hline $\mathrm{C}_{18}$ & 2.50 & 0.00 & 3.37 \\
\hline $\mathrm{C}_{19}$ & 2.56 & 0.00 & 3.45 \\
\hline $\mathrm{C}_{20}$ & 2.51 & 0.00 & 3.38 \\
\hline $\mathrm{C}_{21}$ & 2.31 & 0.00 & 3.11 \\
\hline $\mathrm{C}_{22}$ & 2.18 & 0.00 & 2.94 \\
\hline $\mathrm{C}_{23}$ & 2.08 & 0.00 & 2.81 \\
\hline $\mathrm{C}_{24}$ & 1.91 & 0.00 & 2.58 \\
\hline $\mathrm{C}_{25}$ & 1.85 & 0.00 & 2.49 \\
\hline $\mathrm{C}_{26}$ & 1.65 & 0.00 & 2.23 \\
\hline $\mathrm{C}_{27}$ & 1.50 & 0.00 & 2.03 \\
\hline $\mathrm{C}_{28}$ & 1.38 & 0.00 & 1.86 \\
\hline $\mathrm{C}_{29}$ & 1.25 & 0.00 & 1.69 \\
\hline $\mathrm{C}_{30+}$ & 33.76 & 0.00 & 45.54 \\
\hline Molecular weight & 418.76 & 20.19 & 557.81 \\
\hline $\begin{array}{l}\text { Molecular weight of } \\
\mathrm{C}_{30+}\end{array}$ & 916.89 & 0.00 & 916.89 \\
\hline
\end{tabular}

experimental temperatures from 298.15 to $338.15 \mathrm{~K}$ with a density meter, and the viscosities of the HO sample at temperatures from 298.15 to $368.15 \mathrm{~K}$ and atmospheric 
pressure were measured using a rolling-ball viscometer (see Experimental section for detailed information about the viscometer and density meter). The measured viscosities and densities of the HO sample are shown in Fig. 2.

Figure 2 also shows that the viscosities and densities calculated with Eqs. (1)-(5) are in good agreement with the measured results ( $\mathrm{Li}$ et al. 2011; Moriyoshi et al. 1977).

$\log _{10}\left[\log _{10}(\mu)\right]=-3.2943 \log _{10}(T)+8.9092$

$\rho(T, P)=\frac{\rho_{0}}{1-\beta \ln \left(\frac{B+0.001 P}{B+0.1}\right)}$

where $T$ is the experimental temperature in $\mathrm{K} ; \rho$ is the $\mathrm{HO}$ density in $\mathrm{kg} / \mathrm{m}^{3} ; P$ is the experimental pressure in $\mathrm{kPa}$; and $\mu$ is the $\mathrm{HO}$ viscosity in $\mathrm{mPa}$.

The parameters $\rho_{0}, \beta$, and $B$ are related to temperature based on the following equations (Moriyoshi et al. 1977):

$\rho_{0}=a_{1}+a_{2} T+a_{3} T^{2}$

$B=b_{1}+b_{2} T^{-1}+b_{3} T^{-2}$

$\beta=c_{1}+c_{2} T$

The parameter values $a_{1}, a_{2}, a_{3}, b_{1}, b_{2}, b_{3}, c_{1}$ and $c_{2}$ shown in Eqs. (3)-(5) are $9.414 \times 10^{2}, 9.393 \times 10^{-1}$, $-2.500 \times 10^{-3}, 4.101,-1.752 \times 10^{3}, 2.636 \times 10^{5}$, $-3.271 \times 10^{-3}$, and $3.545 \times 10^{-5}$, respectively, which were determined based on a regression analysis of the density data.

The gases $\mathrm{CO}_{2}, \mathrm{CH}_{4}$, and $\mathrm{C}_{3} \mathrm{H}_{8}$ used in this study had a purity of $99.99 \%$, and the solvent mixture (SM) was

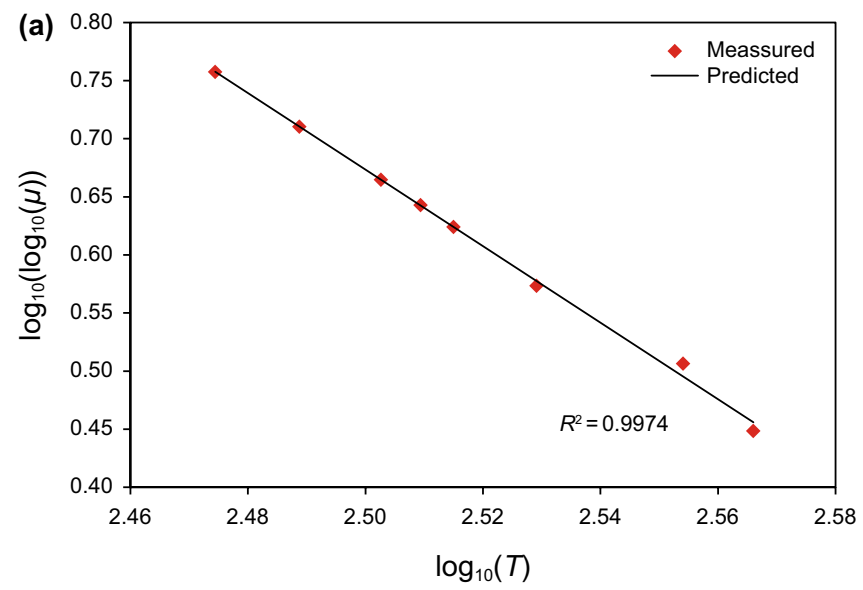

generated by mixing $\mathrm{CH}_{4}, \mathrm{CO}_{2}$, and $\mathrm{C}_{3} \mathrm{H}_{8}$ with a molar fraction ratio of 64:8:28.

\subsection{Experimental setup}

A schematic diagram of the experimental setup is shown in Fig. 3.

The main component of the experimental setup is a PVT system (FY-PVT-1, FEIYU petroleum technology Co. Ltd., China). The PVT cell in a thermal jacket has a length of $35.00 \mathrm{~cm}$ and an inner diameter of $3.57 \mathrm{~cm}$. The PVT cell was made of stainless steel (1Cr18Ni9Ti), and it can withstand up to $70,000 \mathrm{kPa}$ of pressure and temperatures up to $453.15 \mathrm{~K}$. The volume and pressure of the PVT cell are adjusted with a high-pressure pump that is controlled by a control panel attached to a support frame. A high-precision test gauge (Druck Ltd., UK) with an accuracy of $\pm 1 \mathrm{kPa}$ is applied to measure the pressure in the PVT cell, and a temperature controller (SRS-13, Shimadzu, Japan) with an accuracy of $\pm 0.1 \mathrm{~K}$ is used to control the temperature in the PVT cell.

Compared with light or medium oils, PVT tests of heavy oils are more time-consuming because a longer time is needed for gas liberation or dissolution in heavy oil. A special rotary mixing system is designed to accelerate the PVT tests for the HO-SM systems. The rotary mixing system mainly consists of an agitator fully immersed in the fluid and an electromotor located at the bottom of the support frame (Fig. 3). Considering the high viscosity of the HO, the agitator is made of high-density wolfram $\left(15.63 \mathrm{~g} / \mathrm{cm}^{3}\right)$. The electromotor renders the central axis rotates, and then the PVT cell rotates up and down around the central axis in the vertical plane. Due to the movement of the PVT cell, the agitator moves up and down in the PVT cell during this process, which efficiently mixes the heavy oil and the SM at the selected pressures and temperatures. The rotation speed

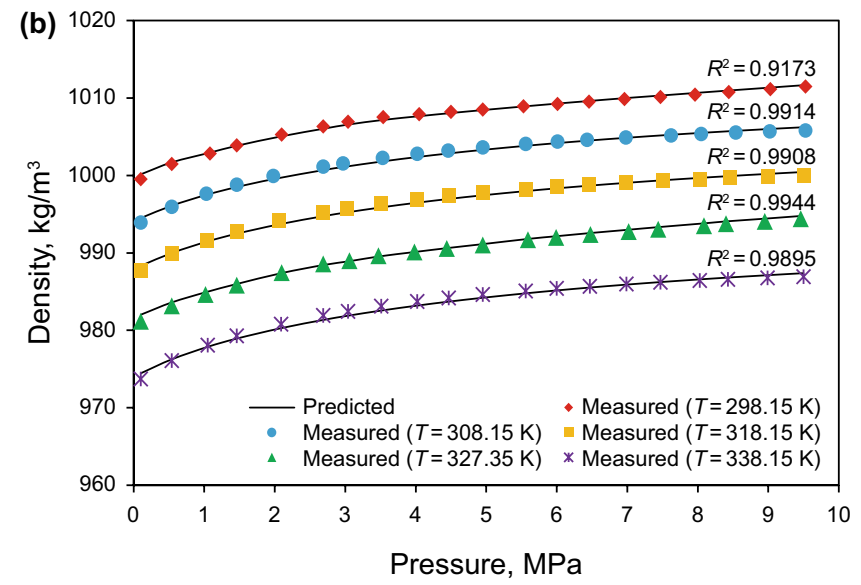

Fig. 2 Measured and predicted viscosities and densities of the VHO: a viscosities and $\mathbf{b}$ densities 


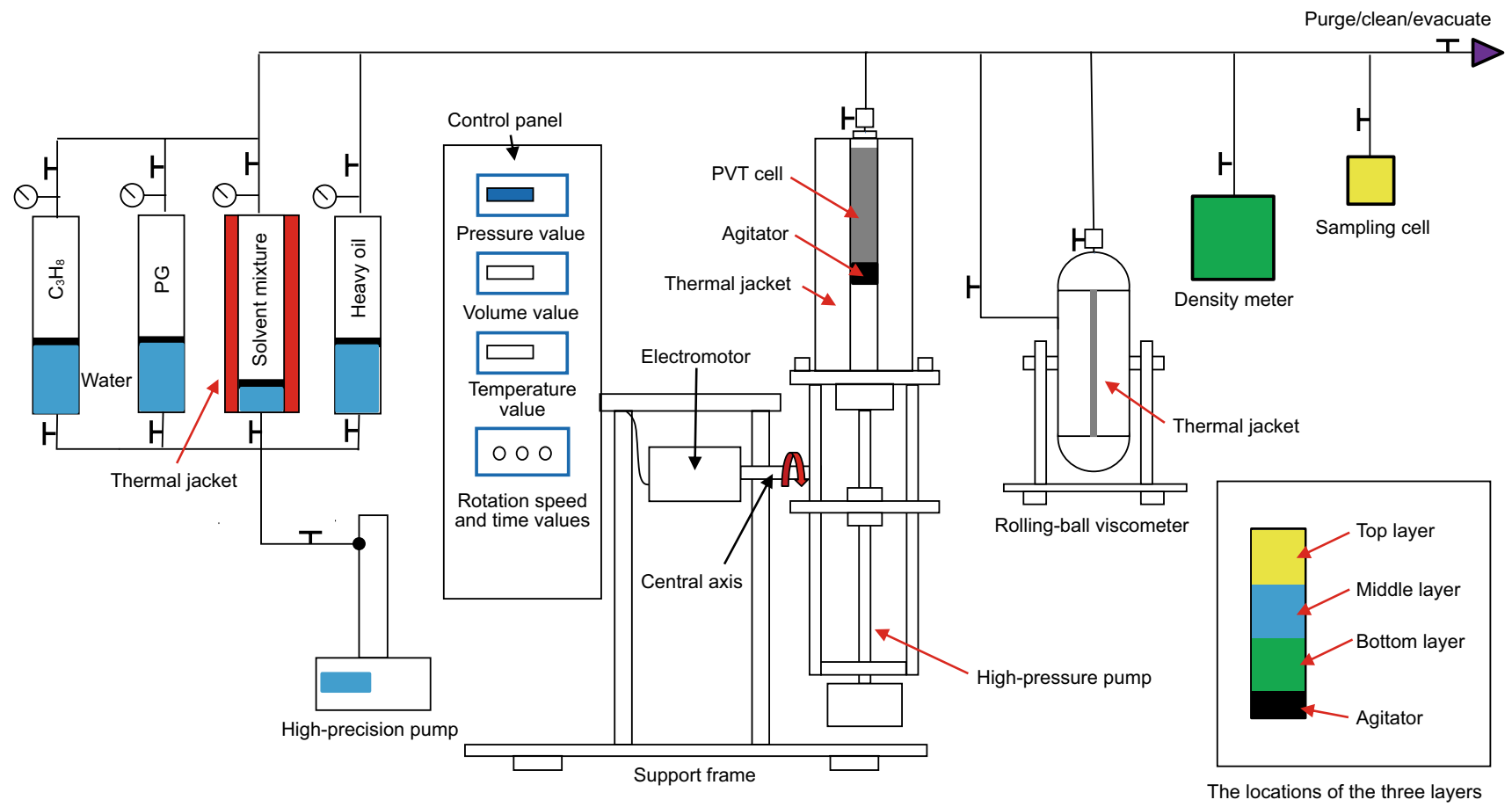

Fig. 3 Schematic diagram of experimental tests

and angle can be set on a control panel. The maximum rotation speed of the PVT cell is 4 circles per minute, and the maximum rotation angle is $180^{\circ}$. The PVT setup provides the pressure, total volume, temperature, rotation speed, and time values on the control panel.

The heavy oil and single solvents were first stored in sample cylinders and then used to form the SM in the transfer cylinder with a thermal jacket. A high-precision pump was employed to transfer the SM from the cylinder to the PVT cell.

A rolling-ball viscometer (CHY-V, SHITIAN electronics Co. Ltd., China) was applied to measure the viscosities of the HO-SM systems. The temperature of the viscometer was maintained via a thermal jacket with an accuracy of $\pm 0.1 \mathrm{~K}$. The measurement limits of the viscometer were $70,000 \mathrm{kPa}$ and $473.15 \mathrm{~K}$, respectively. The viscometer was calibrated using standard viscosity liquids (National Institute of Metrology, China) in the range from 2368.2 to $9308 \mathrm{mPa}$ with a precision of $\pm 5 \mathrm{mPa}$. A density meter (Anton Paar, Austria) was used to determine the densities of the HO-SM systems. This meter was calibrated using water at pressures between 690 and $6900 \mathrm{kPa}$ and temperatures between 283.15 and $323.15 \mathrm{~K}$, and the precision was $\pm 0.001 \mathrm{~g} / \mathrm{cm}^{3}$.

\subsection{Experimental procedures}

Before each test, the PVT cell was cleaned with kerosene and evacuated using a vacuum pump. Subsequently, a desired volume of $\mathrm{HO}$ was transferred into the PVT cell. The HO mass was determined from Eq. (2). According to the mole fraction of the SM (10.29 mol\%) in the studied system and the composition of the $\mathrm{SM}\left(64 \mathrm{~mol} \% \mathrm{CH}_{4}, 8 \mathrm{~mol} \% \mathrm{CO}_{2}\right.$, and $28 \mathrm{~mol} \% \mathrm{C}_{3} \mathrm{H}_{8}$ ), the amounts of $\mathrm{CH}_{4}, \mathrm{CO}_{2}$ and $\mathrm{C}_{3} \mathrm{H}_{8}$ were calculated based on the equation of state for real gases $(\mathrm{Li}$ et al. 2012b). Then, the required amounts of $\mathrm{CH}_{4}, \mathrm{CO}_{2}$, and $\mathrm{C}_{3} \mathrm{H}_{8}$ were introduced into the transfer cylinder to generate the SM. The temperature of the transfer cylinder was kept at the reservoir temperature $(327.35 \mathrm{~K})$ for $24 \mathrm{~h}$ by the thermal jacket to confirm that the PVT cell and transfer cylinder reached the same temperature. Finally, the SM was injected into the PVT cell to constitute the HO-SM system with the desired mole fraction of SM using a high-precision pump.

To accelerate the equilibrium process between the $\mathrm{HO}$ and $\mathrm{SM}$, the PVT cell pressure was increased to $15,000 \mathrm{kPa}$, which was more than the reservoir pressure $(8650 \mathrm{kPa})$. Because the continuous depressurization method is reported to be less accurate than the discrete depressurization method (BadamchiZadeh et al. 2009; Li et al. 2011), the discrete depressurization method was applied to determine the saturation pressure of the HO-SM system in this study, even if it took a longer time to maintain the system in equilibrium. In this process, the PVT cell was incrementally depressurized by increasing the PVT cell volume. At the end of each depressurization step, the rotary mixing system was set to sufficiently stir the HO and SM until the PVT cell pressure stayed constant over a period of time. The equilibrium between the $\mathrm{HO}$ and SM 
was considered to be reached. Consequently, the saturation pressure and the corresponding system volume were determined from the transition point on the pressure-volume $(P-V)$ curve. Finally, the swelling factor of the HO-SM system with a desired mole fraction of SM was calculated as the volume of $\mathrm{HO}-\mathrm{SM}$ system at the saturation pressure divided by the $\mathrm{HO}$ volume at atmospheric pressure. The repeatabilities of the saturation pressure and volume measurements were found to be $\pm 2 \%$ and $\pm 1 \%$, respectively.

After the saturation pressure and swelling factor measurements, the system in the PVT cell was compressed and reequilibrated at the saturation pressure. Then, a certain amount of the mixture at the top of the PVT cell was passed to the density meter and viscometer, and the viscosity and density of the system at the saturation pressure were determined.

In addition, to examine the change of viscosities and densities of the mixture at different depths after the in situ heavy oil upgrading process, the remaining mixture $\left(150 \mathrm{~m}^{3}\right)$ in the PVT cell was kept at the saturation pressure without stirring for 45 days. Then, the mixture was artificially divided into three layers (around $50 \mathrm{~m}^{3}$ ) shown in Fig. 3, according to the volume requirements of the falling ball viscometer and density meter. Overall, there is no clearly defined boundary between any two layers, and such a division is subjective. In this process, the oil of the top layer was divided into three oil samples (the volume of each sample was around $15 \mathrm{~m}^{3}$ ), and they were introduced into the falling ball viscometer and the density meter for measuring their viscosity and density at saturation pressure in turn. The average values of the three measurements represent the viscosity and density of the top layer. Following the abovementioned process, the viscosities and densities of middle layer and bottom layer at deeper locations of the PVT cell were measured one by one. The

\section{Theoretical section}

\subsection{Equation of state}

The PR-EOS model is used and given by Eqs. (6)-(8) (Peng and Robinson 1976):

$P=\frac{T R}{V-b}-\frac{a}{b(V-b)+V(V+b)}$

$a=0.457235 \alpha \frac{R^{2} T_{\mathrm{c}}^{2}}{P_{\mathrm{c}}}$

$b=\frac{0.0777969 R T_{c}}{P_{c}}$

where $R$ is the universal gas constant in $\mathrm{kPa} \mathrm{m}^{3} /(\mathrm{K} \mathrm{kmol})$; $a$ is the attraction parameter; $V$ is the molar volume of the HO-SM system in $\mathrm{m}^{3} / \mathrm{kmol} ; b$ is a constant related to critical properties in $\mathrm{m}^{3} / \mathrm{kmol} ; P_{\mathrm{c}}$ is the critical pressure of each component in the HO-SM system in $\mathrm{kPa} ; \alpha$ is the dimensionless function; and $T_{\mathrm{c}}$ is the critical temperature of each component in the HO-SM system in $\mathrm{K}$.

The commonly used $\alpha$ function is a Soave-type function (Peng and Robinson 1976):

$\alpha=\left[1+\left(0.37464+1.54226 \omega-0.26992 \omega^{2}\right)\left(1-T_{\mathrm{r}}^{0.5}\right)\right]^{2}$

where $\omega$ and $T_{\mathrm{r}}$ are the acentric factor and reduced temperature of each component in the HO-SM system, respectively.

However, according to previous studies, the following $\alpha$ function can provide a more accurate estimation of the saturation pressure compared with the Soave-type function (Li and Yang 2011):

$\alpha=\exp \left\{\begin{array}{l}\left(0.13280-0.05052 \omega+0.25948 \omega^{2}\right)\left(1-T_{\mathrm{r}}\right)+ \\ 0.81769 \ln \left[1+\left(0.31355+1.86745 \omega-0.52604 \omega^{2}\right)\left(1-\sqrt{T_{\mathrm{r}}}\right)\right]^{2}\end{array}\right\}$

repeatabilities of the density and viscosity measurements were found to be $\pm 2 \%$ and $\pm 3 \%$, respectively.

In this study, HO-SM systems with varied solvent mole fractions (10.29-33.54 mol\%) were prepared and tested at $327.35 \mathrm{~K}$ following the aforementioned procedure. After the measurements of the saturation pressures, swelling factors, viscosities, and densities at the lowest mole fraction of SM were obtained, the mole fraction of SM was increased, and the measurements were repeated at the higher mole fraction of SM. Thus, the effects of the mole fraction of SM on the phase behaviors of the HO-SM systems were systematically investigated.
The studied HO-SM system is a mixture. Therefore, the $a$ and $b$ used in Eq. (6) should be calculated by the following mixing rules.

$$
\begin{aligned}
& a=\sum_{i=1}^{n} \sum_{j=1}^{n} x_{i} x_{j}\left(1-\delta_{i j}\right) \sqrt{a_{i} a_{j}} \quad(i, j=1,2,3,4) \\
& b=\sum_{i=1}^{n} x_{i} b_{i}
\end{aligned}
$$

where $n$ is the component number in the HO-SM system; $\delta_{i j}$ is the empirically determined binary interaction parameter (BIP) between components $i$ and $j$; $x$ is the mole fractions 
of each component in the HO-SM system. In this study, the heavy oil is characterized as a single pseudocomponent, $\mathrm{HO}$ as its utilization in PR-EOS model can accurately predict the phase behavior of solvent-heavy oil systems, as proven by previous research (Li and Yang 2013; Li et al. 2011, 2012c; Yang et al. 2014). Therefore, totally four components $\left(\mathrm{C}_{3} \mathrm{H}_{8}\right.$, $\mathrm{CO}_{2}, \mathrm{CH}_{4}$, and $\mathrm{HO}$ ) are used to characterize the HO-SM system in this study.

\subsection{BIP correlations}

The BIP between any two components must be calculated based on Eq. (11). Because $\mathrm{C}_{3} \mathrm{H}_{8}, \mathrm{CO}_{2}$, and $\mathrm{CH}_{4}$ are pure components, the BIPs for the $\mathrm{C}_{3} \mathrm{H}_{8}-\mathrm{CO}_{2}$ pair $\left(\delta_{12}\right)$, $\mathrm{C}_{3} \mathrm{H}_{8}-\mathrm{CH}_{4}$ pair $\left(\delta_{13}\right)$, and $\mathrm{CO}_{2}-\mathrm{CH}_{4}$ pair $\left(\delta_{23}\right)$ can be determined by the following equation (Chueh and Prausnitz 1967; Oellrich et al. 1981):

$\delta_{i j}=1-\left[\frac{2 \sqrt{V_{\mathrm{c} i}^{1 / 3} V_{\mathrm{c} j}^{1 / 3}}}{V_{\mathrm{c} i}^{1 / 3}+V_{\mathrm{c} j}^{1 / 3}}\right]^{1.2} \quad(i, j=1,2,3,4)$

where $V_{\mathrm{c}}$ is the critical molar volume of each component in the HO-SM system.

The BIPs for the $\mathrm{C}_{3} \mathrm{H}_{8}$-HO pair $\left(\delta_{14}\right), \mathrm{CO}_{2}$ - $\mathrm{HO}$ pair $\left(\delta_{24}\right)$, and $\mathrm{CH}_{4}$-HO pair $\left(\delta_{34}\right)$ are determined with the following correlations that were developed by fitting experimental solubility data, as recommended by several researchers ( $\mathrm{Li}$ and Yang 2013; Li et al. 2011, 2012c; Yang et al. 2014).

$\mathrm{C}_{3} \mathrm{H}_{8}$-HO pair $\quad \delta_{14}=-0.4560 \frac{T}{T_{\mathrm{c}}}+0.1817$

$\mathrm{CO}_{2}$-HO pair $\quad \delta_{24}=-0.5462 \frac{T}{T_{\mathrm{c}}}-0.4596 \gamma-0.0238 \omega+0.7523$

$\mathrm{CH}_{4}-\mathrm{HO}$ pair $\quad \delta_{34}=-0.8060 \frac{T}{T_{\mathrm{c}}}-0.8550 \gamma-0.0809 \omega+1.1880$

where $\gamma, \omega$, and $T_{\mathrm{c}}$ are the specific gravity, acentric factor, and critical temperature of $\mathrm{HO}$, respectively.

The critical properties $\left(T_{\mathrm{c}}, \omega\right.$, and $\left.P_{\mathrm{c}}\right)$ of $\mathrm{CO}_{2}, \mathrm{CH}_{4}$, and $\mathrm{C}_{3} \mathrm{H}_{8}$ are available in the literature ( $\mathrm{Li}$ and Yang 2013; Yang et al. 2014), and the critical properties of HO can be obtained from the equations in "Appendix".

\subsection{Swelling factor and density}

The swelling factor is of great importance for evaluating the validity of a solvent during solvent-based processes.
Generally, oil swelling caused by solvent dissolution can increase heavy oil saturation and mobility in porous media (Li et al. 2013). Therefore, a larger swelling factor is beneficial for the performance of a solvent-based process.

The swelling factor, $f$, of the HO-SM system is defined as follows ( $\mathrm{Li}$ et al. 2011):

$f=\frac{V_{2}}{V_{1}(1-S)}$

where $S$ is the mole fraction of the SM, $V_{1}$ is the molar volume of $\mathrm{HO}$ at $101.32 \mathrm{kPa}$ in $\mathrm{m}^{3} / \mathrm{kmol}$, and $V_{2}$ is the molar volume of the HO-SM system at the saturation pressure and reservoir temperature in $\mathrm{m}^{3} / \mathrm{kmol}$.

In this study, three volume translation methods were used to improve swelling factor prediction. Notably, these methods have no impact on the prediction of saturation pressures (Peneloux et al. 1982). The corrected value of $V_{2}$ is calculated as follows:

$V_{2}=V-\sum_{i=1}^{n} x_{i} C_{i}$

$C=s \times b$

where $C$ is the correction parameter; and $s$ is the shift parameter. This shift parameter can be predicted by the equation developed by Jhaveri and Youngren (1988):

$s=1-\frac{d}{M^{e}}$

where $M$ is the molecular weight and $e$ and $d$ are constants equal to 0.1823 and 2.258 , respectively.

Furthermore, Peneloux et al. (1982) and Twu and Chan (2009) proposed two correlations to estimate $C$, as shown in Eqs. (21) and (22):

$C=0.40768\left(\frac{R T_{\mathrm{c}}}{P_{\mathrm{c}}}\right)\left(0.29441-Z_{\mathrm{RA}}\right)$

$C=0.406501\left(\frac{R T_{\mathrm{c}}}{P_{\mathrm{c}}}\right)\left(0.260484-Z_{\mathrm{RA}}\right)$

where $Z_{\mathrm{RA}}$ is the Rackett's compressibility factor of VHO, which can be expressed as follows:

$Z_{\mathrm{RA}}=\left(\frac{M P_{\mathrm{c}}}{R T_{\mathrm{c}} \gamma}\right)^{1 /\left[1+\left(1-T / T_{\mathrm{c}}\right)^{2 / 7}\right]}$

The aforementioned volume translation methods were evaluated based on their accuracy for predicting the swelling factors of the HO-SM systems with various mole fractions of SM. 
The density of the HO-SM system can be calculated as follows:

$\rho_{\text {mix }}=\frac{n_{\mathrm{o}} M_{\mathrm{o}}+n_{\mathrm{g}} M_{\mathrm{g}}}{V_{\mathrm{o}} f}$
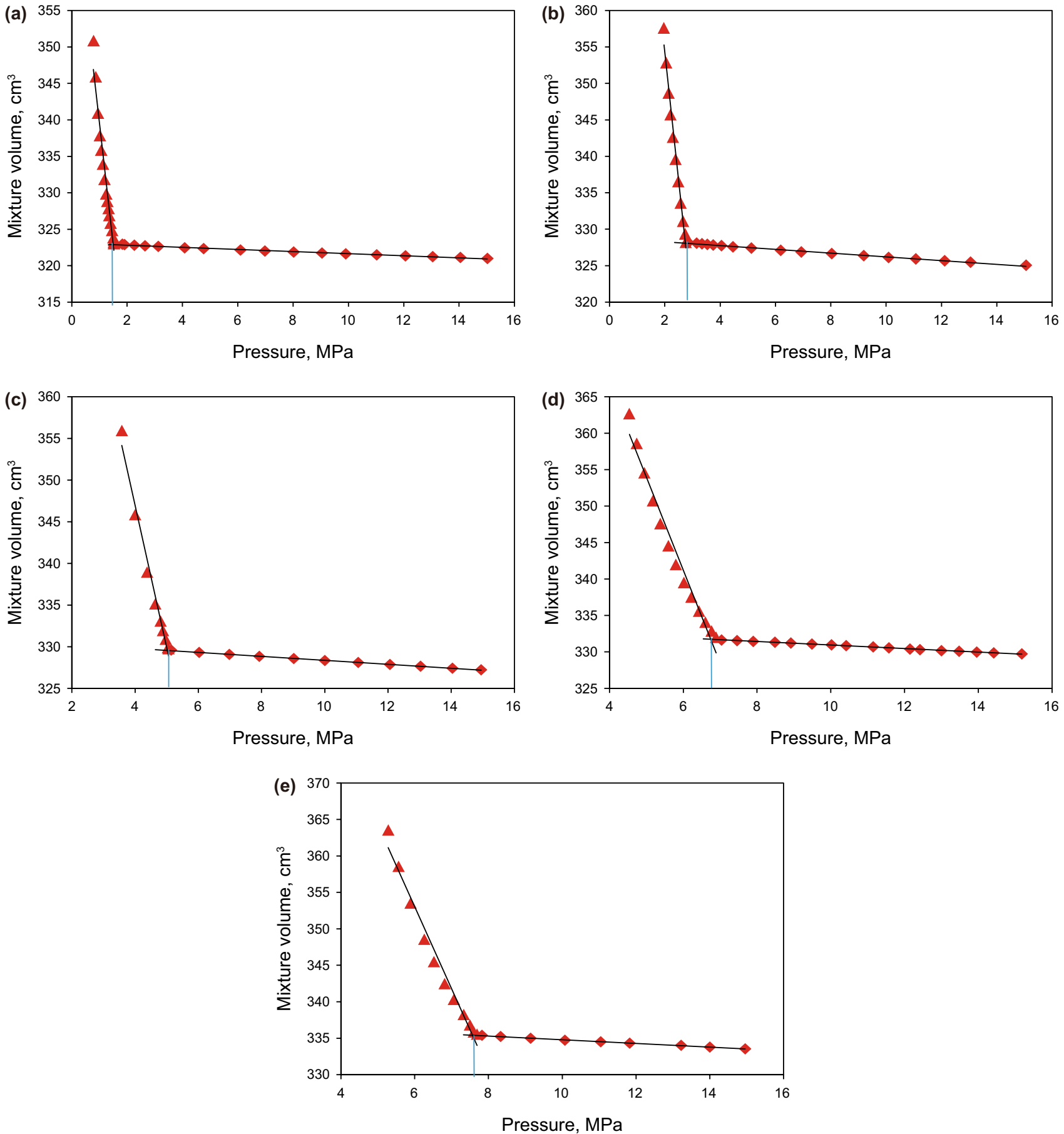

Fig. 4 Measured $P-V$ curves of the HO-SM systems with varied mole fractions: a $10.29 \mathrm{~mol} \% \mathrm{SM}$, b $18.66 \mathrm{~mol} \% \mathrm{SM}$, c $26.59 \mathrm{~mol} \% \mathrm{SM}$, d $31.50 \mathrm{~mol} \% \mathrm{SM}$, and e $33.54 \mathrm{~mol} \% \mathrm{SM}$ 


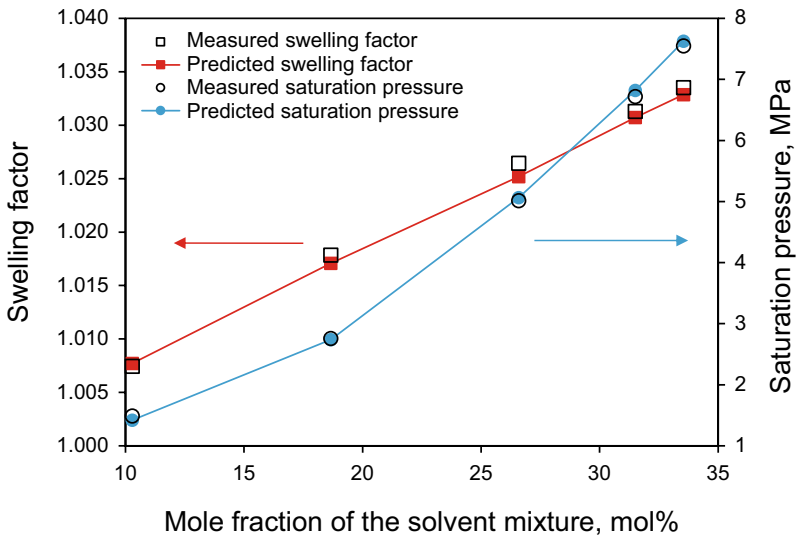

Fig. 5 Measured and predicted saturation pressures and swelling factors of the HO-SM systems for varied mole fractions of SM

\section{Results and discussion}

\subsection{Discussion on the experimental findings}

Figure 4 demonstrates the $P-V$ curves of the HO-SM systems with varied mole fractions of SM.

The saturation pressures and the corresponding volumes were obtained based on the transition points of the curves shown in Fig. 4. The measured saturation pressures and calculated swelling factors at different mole fractions of SM are plotted in Fig. 5.

As shown in Fig. 5, the saturation pressures considerably increase as the mole fraction of SM increases, implying that a high pressure is needed if a large amount of injected SM is dissolved in the HO during solvent-based processes. In addition, the high values of the measured saturation pressures indicate that the dissolved SM is released from the oil phase during the production period of CSI processes, providing sufficient energy for driving solution gas. Moreover, because a high mole fraction of SM exists even at low pressures (Fig. 5), the viscosity and density of the system remain low during the late stage of the production period in CSI processes.

Figure 5 also shows that the measured swelling factor curve increases almost linearly with increasing mole fraction of SM, which suggests that the dissolution of the SM leads to the swelling of the HO. The HO swells 1.034 times due to the dissolution of the $33.54 \mathrm{~mol} \%$ SM. However, the magnitude of swelling is not as drastic as that for light oils, which can swell by approximately $10 \%$ of their original volume due to significant solvent dissolution (Luo et al. 2007a). A large swelling factor is beneficial for the performance of solventbased processes because the enhanced oil swelling effect can lead to an increased relative permeability in the oil phase and enhanced mobile oil saturation in heavy reservoirs.

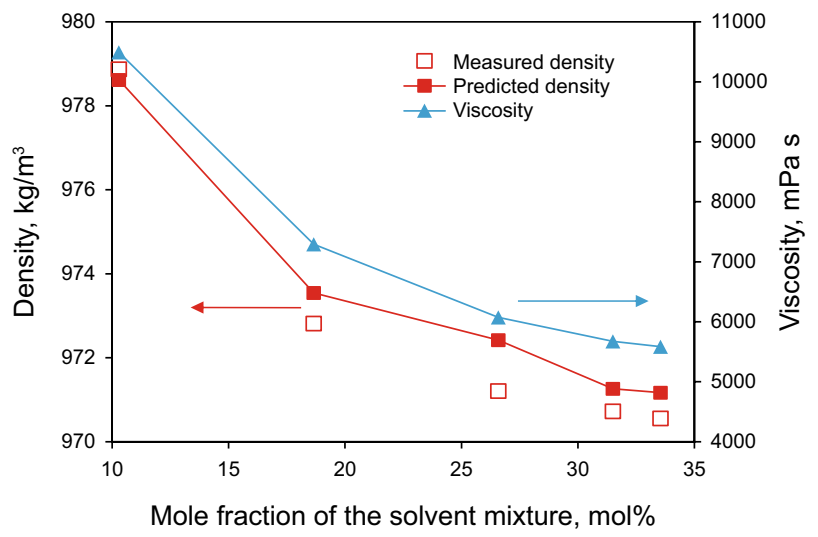

Fig. 6 Measured viscosities, and measured and predicted densities of the $\mathrm{HO}-\mathrm{SM}$ systems at saturation pressures

Viscosity and density reduction is an important mechanism of solvent-based processes for enhancing heavy oil recovery. Solvent can significantly reduce the oil viscosity and density, even at a relatively low pressure (Kariznovi et al. 2011). The measured viscosities and densities of the HO-SM systems at saturation pressures are shown in Fig. 6.

Figure 6 clearly shows that the viscosities and densities of the systems generally decrease as the mole fraction of $\mathrm{SM}$ in each system increases, as expected. For example, the viscosity and density of the HO-SM system were reduced from $16,105.40 \mathrm{mPa}$ s and $0.9812 \mathrm{~g} / \mathrm{cm}^{3}$ to $5585.70 \mathrm{mPa} \mathrm{s}$ and $0.9706 \mathrm{~g} / \mathrm{cm}^{3}$ with the dissolution of a $33.54 \% \mathrm{SM}$. Therefore, it can be inferred that increasing the dissolution of the SM at a high pressure or a large gas injection volume is beneficial for performance in solvent-based processes.

Figure 7 presents the viscosities and densities of the HO-SM systems in the three different layers at saturation pressures after 45 days of equilibrium.

As shown in Fig. 7, regardless of the mole fraction of the $\mathrm{SM}$, the viscosities and densities of the HO-SM systems increase with increasing depth in the PVT cell. For example, when the mole fraction of the SM is $10.29 \%$, the viscosity and density of the bottom layer are $11,174.70 \mathrm{mPa} s$ and $0.9841 \mathrm{~g} / \mathrm{cm}^{3}$, respectively, which are approximately 1.25 and 1.01 times those values of $8951.06 \mathrm{mPa}$ s and $0.9707 \mathrm{~g} /$ $\mathrm{cm}^{3}$ of the top layer. Therefore, the HO-SM systems become heterogeneous and exhibit different physicochemical properties inside the PVT cell after 45 days of equilibrium.

This finding can contribute the in situ heavy oil upgrading under the experimental conditions. After the HO-SM systems were in a static state for 45 days, some light components were continuously extracted from the $\mathrm{HO}$ at the top of the PVT cell. Moreover, the SM concentration in the $\mathrm{HO}$ resulted in asphaltene precipitation, and asphaltene was deposited at the bottom of the PVT cell. Therefore, the top layer becomes an oil phase enriched with solvent. 

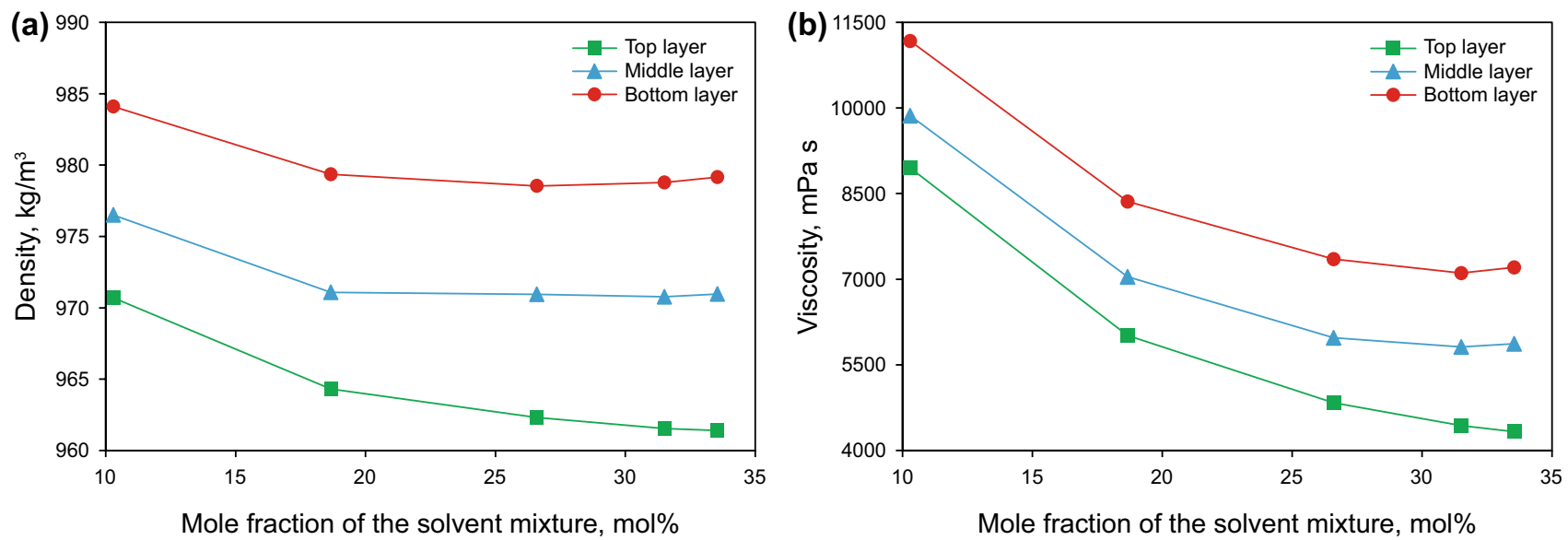

Fig. 7 Measured viscosities and densities of the HO-SM systems in three different layers at the saturation pressure after 45 days of equilibrium: $\mathbf{a}$ densities and $\mathbf{b}$ viscosities

Table 4 Calculated critical properties of all the components

\begin{tabular}{lllllll}
\hline Component & $T_{\mathrm{c}}$ & $P_{\mathrm{c}}$ & $Z_{\mathrm{RA}}$ & $\omega$ & $V_{\mathrm{c}}$ & References \\
\hline $\mathrm{C}_{3} \mathrm{H}_{8}$ & 369.80 & 4246 & 0.2763 & 0.1520 & 0.2030 & Li et al. (2011) \\
$\mathrm{CO}_{2}$ & 304.14 & 7378 & 0.2736 & 0.2238 & 0.0940 & Li et al. (2011) \\
$\mathrm{CH}_{4}$ & 190.55 & 4600 & 0.2876 & 0.0080 & 0.0990 & Yang et al. (2014) \\
Heavy oil (VHO) & 951.53 & 1010 & 0.2301 & 1.1556 & N/A & "Appendix" \\
\hline
\end{tabular}

Additionally, the middle layer is HO with dissolved SM, and the bottom layer becomes $\mathrm{HO}$ with heavy components.

Figure 7 shows that the viscosities and densities of the top layer gradually decrease as the mole fraction of the SM increases. However, the viscosities and densities of the middle and bottom layers initially decrease, and then a slight increase is observed. This result occurs because the top layer is mainly light components. When the mole fraction of the SM increases, more dissolution of the SM in the solvent-enriched oil phase causes decreases in the viscosity and density of the top layer. However, for the mixtures in the middle and bottom layers, the precipitation of asphaltene significantly increases when the mole fraction of SM exceeds $31.50 \mathrm{~mol} \%$, which contributes to slight increases in the viscosity and density of $\mathrm{HO}$ in the bottom layer, as shown in Fig. 7. These observations are consistent with the results obtained in previous studies involving asphaltene precipitation tests (Luo et al. 2007b).

In a field application, if a large amount of SM is injected into the HO reservoir, the generated asphaltene precipitation can result in the in situ heavy oil upgrading. When an additional SM is injected and dissolved into the upgraded $\mathrm{HO}$, the viscosity and density of the in situ upgraded $\mathrm{HO}$ can be further reduced. Therefore, the HO in the top layer can be easily produced via solvent-based processes. However, the $\mathrm{HO}$ in the bottom layer, which mainly contains heavy
Table 5 BIPs for all the component pairs

\begin{tabular}{lllll}
\hline Component & $\mathrm{C}_{3} \mathrm{H}_{8}$ & $\mathrm{CO}_{2}$ & $\mathrm{CH}_{4}$ & $\begin{array}{l}\text { Heavy } \\
\text { oil } \\
\text { (VHO) }\end{array}$ \\
\hline $\mathrm{C}_{3} \mathrm{H}_{8}$ & 0 & 0.1350 & 0.0085 & 0.0248 \\
$\mathrm{CO}_{2}$ & 0.1350 & 0 & $4.5 \times 10^{-5}$ & 0.0859 \\
$\mathrm{CH}_{4}$ & 0.0085 & $4.5 \times 10^{-5}$ & 0 & 0.0217 \\
Heavy oil (VHO) & 0.0248 & 0.0859 & 0.0217 & 0 \\
\hline
\end{tabular}

components, including asphaltene deposits, is left behind in the $\mathrm{HO}$ reservoir.

Overall, the phase behavior data for the HO-SM systems demonstrate that the SM exhibit promising application potential for heavy oil recovery in solvent-based processes. The dominant mechanisms include combined viscosity and density reduction, solution gas driving, oil swelling, and the in situ upgrading of heavy oil.

\subsection{Discussion on the prediction results}

The calculated critical properties for all the components and BIPs for all the component pairs are shown in Tables 4 and 5. The saturation pressures, swelling factors, and densities 


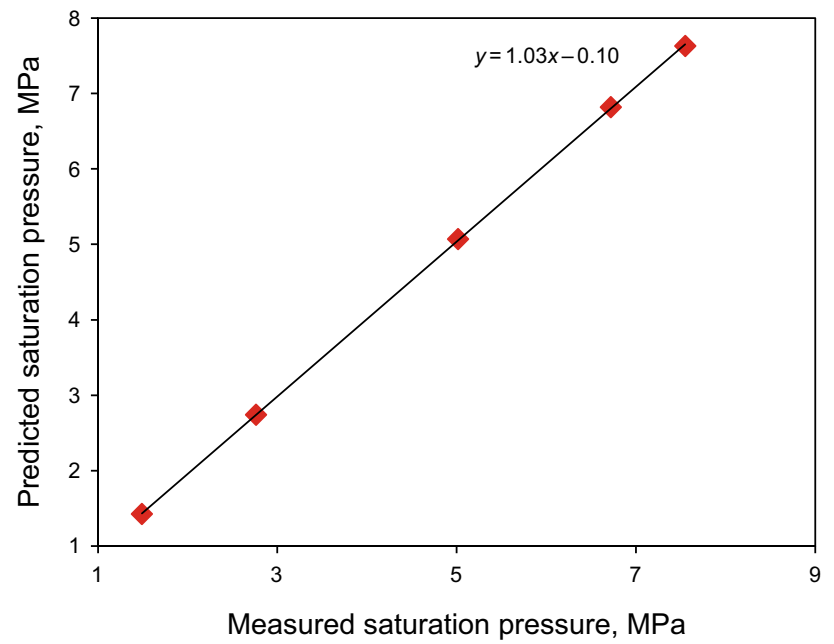

Fig. 8 Regression for measured and predicted saturation pressures

for the HO-SM systems with varied mole fractions of SM were predicted by the PR-EOS model with Eqs. (6), (17), and (24) (Figs. 5 and 6). As shown in Figs. 5 and 6, the measured and predicted saturation pressures, swelling factors, and densities exhibit good agreement.

To quantitatively evaluate the accuracy of the predicted saturation pressures, swelling factors, and densities, three statistical methods were utilized: linear regression analysis, average error percentage $\left(A E P=\frac{1}{n} \sum_{i=1}^{n}\left|\frac{X_{i}^{\text {pred }}-X_{i}^{\text {meas }}}{X_{i}^{\text {meas }}}\right|\right.$, where $n$ is the number of measured mole fractions of SM and $X_{i}^{\text {pred }}$ and $X_{i}^{\text {meas }}$ are the predicted and measured saturation pressure, swelling factor, or density values, respectively), and analysis of variance tables (difference between measured and predicted values).

As shown in Fig. 8 and Table 6, the slope $(A)$ of the linear correlation $(y=A x+B)$ between predicted and measured saturation pressures is close to 1 , and the correlation coefficient is 1.00 . In addition, the $A E P$ value between the measured and predicted results is $1.77 \%$. All the results clearly indicate that good agreement exists between the measured and predicted results.

The calculated analysis of variance table for saturation pressures is shown in Table 7 , where $D F$ is the degrees of freedom, $S S$ is the sum of the squares, $M S$ is the mean squares, $F$ is a variance-related statistical parameter. A detailed description of the parameters in Table 7 can be
Table 7 Analysis of variance table for regression analysis of the measured and predicted saturation pressures

\begin{tabular}{llrll}
\hline Source & $D F$ & \multicolumn{1}{c}{$S S$} & $M S$ & $F$ \\
\hline Regression & 1 & 27.78 & 5.56 & $64,619.31$ \\
Residual & 3 & 0.00 & 0.00 & \\
Total & 4 & 27.78 & & \\
\hline
\end{tabular}

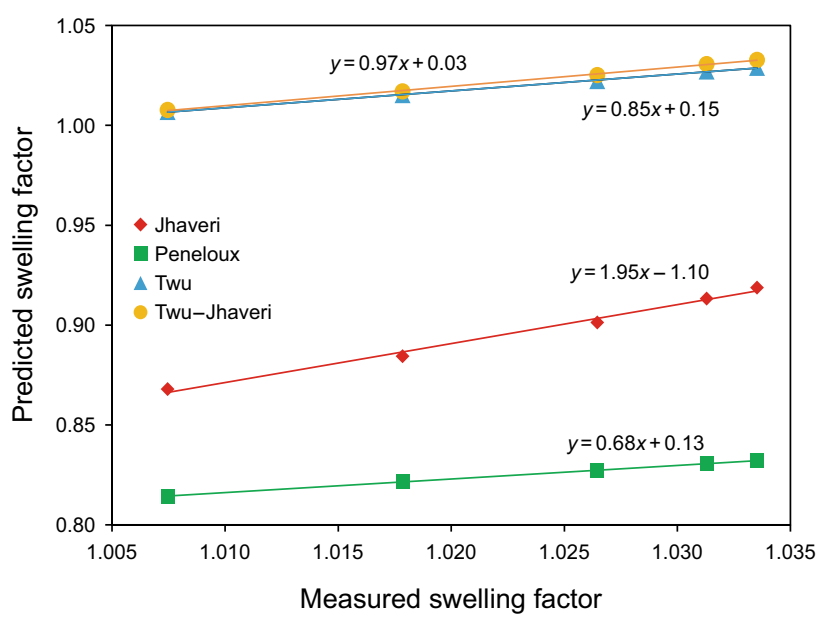

Fig. 9 Regression results for measured and predicted swelling factors

found elsewhere (Sun et al. 2017b, 2018b; Zendehboudi et al. 2011). As shown in Table 7, the calculated $F$ value is $64,619.31$, which is much higher than the critical value of $F_{\mathrm{c}}(7.71)$ and provides strong evidence against the null hypothesis. Therefore, all statistical analyses confirmed the suitability of the prediction method used in this study.

To evaluate the effects of volume translation methods on the prediction of swelling factors, the swelling factors were calculated using the Jhaveri method (Eq. 19), Peneloux method (Eq. 21), Twu method (Eq. 22), and Twu-Jhaveri method, respectively. The Twu-Jhaveri method is a combined calculation method in which the correction factors for the solvent components $\left(\mathrm{CH}_{4}, \mathrm{CO}_{2}\right.$, and $\left.\mathrm{C}_{3} \mathrm{H}_{8}\right)$ and $\mathrm{HO}$ component are calculated by the Jhaveri method and Twu method, respectively.

The predicted swelling factors are shown in Fig. 9. Notably, the Twu-Jhaveri method is the most reliable method for predicting the swelling factors of the HO-SM systems in comparison with the other three methods. The values

Table 6 Regression for the measured and predicted saturation pressures

\begin{tabular}{lcccccc}
\hline Coefficient & Value & Upper 95\% & Lower 95\% & Standard error & Correlation coefficient & AEP, $\%$ \\
\hline$A$ & 1.03 & 1.04 & 1.01 & 0.00 & 1.00 \\
$B$ & -0.10 & -0.03 & -0.16 & 0.02 & \\
\hline
\end{tabular}


Table 8 Regression for the measured and predicted swelling factors by different methods

\begin{tabular}{llccccc}
\hline Method & Coefficient & Value & Upper 95\% & Lower 95\% & Standard error & $\begin{array}{c}\text { Correlation coef- } \\
\text { ficient }\end{array}$ \\
\hline Jhaveri & $A$ & 1.95 & 2.27 & 1.63 & 0.10 & 0.99 \\
\multirow{2}{*}{ Peneloux } & $B$ & -1.10 & -0.77 & -1.43 & 0.10 & 12.33 \\
& $A$ & 0.68 & 0.70 & 0.65 & 0.01 & 1.00 \\
Twu & $B$ & 0.13 & 0.16 & 0.10 & 0.01 & 1.00 \\
\multirow{2}{*}{ Twu-Jhaveri } & $A$ & 0.85 & 0.89 & 0.80 & 0.01 & 0.36 \\
& $B$ & 0.15 & 0.20 & 0.10 & 0.02 & 0.00 \\
& $B$ & 0.97 & 1.04 & 0.89 & 0.02 & 0.07 \\
\hline
\end{tabular}

Table 9 Analysis of variance table for the regression analysis of the measured and predicted swelling factors

\begin{tabular}{llllll}
\hline Method & Source & $D F$ & $S S$ & $M S$ & $F$ \\
\hline Jhaveri & Regression & 1 & $1.75 \mathrm{E}-03$ & $3.49 \mathrm{E}-04$ & 378 \\
& Residual & 3 & $1.38 \mathrm{E}-05$ & $4.61 \mathrm{E}-06$ & \\
& Total & 4 & $1.76 \mathrm{E}-03$ & & \\
Peneloux & Regression & 1 & $2.12 \mathrm{E}-04$ & $4.24 \mathrm{E}-05$ & 7560 \\
& Residual & 3 & $8.41 \mathrm{E}-08$ & $2.80 \mathrm{E}-08$ & \\
& Total & 4 & $2.12 \mathrm{E}-04$ & & \\
Twu & Regression & 1 & $3.29 \mathrm{E}-04$ & $6.57 \mathrm{E}-05$ & 3120 \\
& Residual & 3 & $3.16 \mathrm{E}-07$ & $1.05 \mathrm{E}-07$ & \\
& Total & 4 & $3.29 \mathrm{E}-04$ & & \\
Twu-Jhaveri & Regression & 1 & $4.29 \mathrm{E}-04$ & $8.58 \mathrm{E}-05$ & 1780 \\
& Residual & 3 & $7.24 \mathrm{E}-07$ & $2.41 \mathrm{E}-07$ & \\
& Total & 4 & $4.30 \mathrm{E}-04$ & & \\
\hline
\end{tabular}

predicted by the other methods are lower than the measured values, especially those obtained by the Jhaveri method and the Peneloux method.

The statistical analysis results show that the slope $(A)$ of the linear correlation obtained by the Twu-Jhaveri method is 0.97 (Table 8 and Fig. 9). The slopes of the linear correlations obtained by the Jhaveri method, Peneloux method, and Twu method are $1.95,0.68$, and 0.85 , respectively. A comparison of the slope values indicates that the value obtained by the Twu-Jhaveri method is 1.00 , which implies that the Twu-Jhaveri method adequately reflects the experimental data. In addition, the linear correlations between the predicted and measured data obtained by the four methods all have high correlation coefficient values, and the $F$ values are much greater than the corresponding $F_{\mathrm{c}}$ value (7.71), which highlights the reliability of the regression results (Table 9).

In addition, Table 8 shows that the swelling factors can be reproduced by the Twu-Jhaveri method with an $A E P$ value of $0.07 \%$, and $A E P$ values of $12.33 \%, 19.36 \%$, and

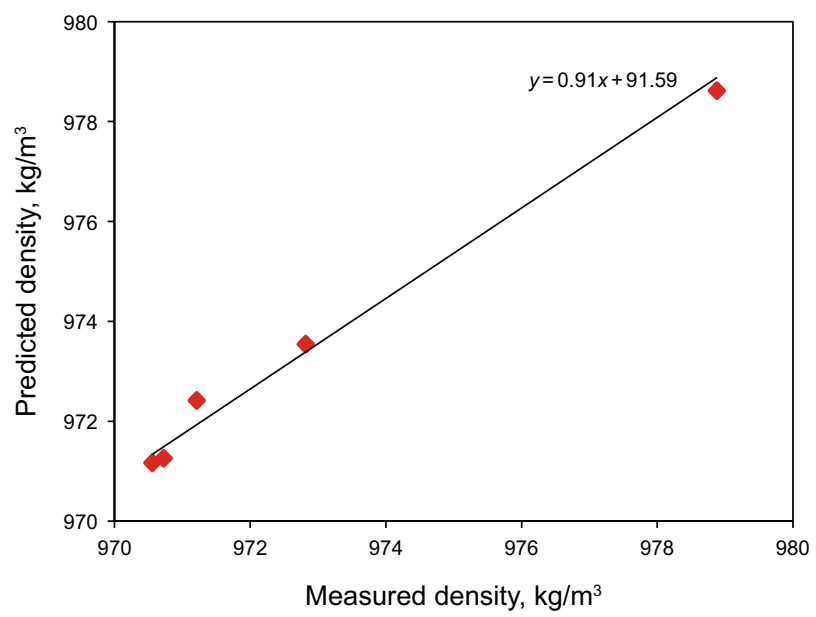

Fig. 10 Regression for measured and predicted densities

$0.32 \%$ for swelling factors were obtained by the Jhaveri method, Peneloux method, and Twu method, respectively.

As shown in Fig. 10 and Table 10, the statistical analysis results show that the slope $(A)$ of the linear correlation between predicted and measured densities is 0.91 , the correlation coefficient is 0.99 , and the $A E P$ value between the measured and predicted results is $0.07 \%$. As shown in Table 11, the calculated $F$ value is 308.79 , which is much higher than the critical value of $F_{\mathrm{c}}(7.71)$, which highlights the reliability of the regression results.

Overall, the theoretical methodology based on the PREOS model, the $\alpha$ function, the selected BIP correlations, and the Twu-Jhaveri method can accurately predict the saturation pressures, swelling factors, and densities for the HO-SM systems with varied mole fractions of SM. 
Table 10 Regression for the measured and predicted densities

\begin{tabular}{lrccccc}
\hline Coefficient & Value & Upper 95\% & Lower 95\% & Standard error & Correlation coefficient & AEP, $\%$ \\
\hline$A$ & 0.91 & 1.03 & 0.72 & 0.05 & 0.99 \\
$B$ & 91.59 & 275.86 & -32.68 & 48.47 & & 0.07 \\
\hline
\end{tabular}

Table 11 Analysis of variance table for regression analysis of the measured and predicted densities

\begin{tabular}{llrll}
\hline Source & $D F$ & \multicolumn{1}{c}{$S S$} & $M S$ & $F$ \\
\hline Regression & 1 & 37.39 & 7.48 & 308.79 \\
Residual & 3 & 0.36 & 0.12 & \\
Total & 4 & 37.75 & & \\
\hline
\end{tabular}

\section{Conclusions}

1. The theoretical methodology based on the PR-EOS model, the $\alpha$ function, the selected BIP correlations, and the Twu-Jhaveri method can accurately predict the saturation pressures, swelling factors, and densities of the $\mathrm{SM}\left(64 \mathrm{~mol} \% \mathrm{CH}_{4}, 8 \mathrm{~mol} \% \mathrm{CO}_{2}\right.$, and $\left.28 \mathrm{~mol} \% \mathrm{C}_{3} \mathrm{H}_{8}\right)$ for HO systems, with an average error percentages of $1.77 \%$ for saturation pressures, $0.07 \%$ for swelling factors, and $0.07 \%$ for densities.

2. The Twu-Jhaveri method was the most accurate method of predicting swelling factors for the HO-SM systems in comparison with the Jhaveri method, Peneloux method, and the Twu method. The swelling factors predicted by the Jhaveri method, Peneloux method, and the Twu method are lower than the experimental values, especially those obtained by the Jhaveri method and the Peneloux method.

3. As the mole fraction of SM increases, the saturation pressures and swelling factors considerably increase, and the viscosity and density of the HO-SM systems decrease. Therefore, an increase in the dissolution of the $\mathrm{SM}$ at high injection pressures or high gas injection volumes is beneficial for solvent-based processes.

4. The HO-SM systems become heterogeneous and exhibit different physicochemical properties after 45 days of equilibrium. The viscosity and density of the systems increase with increasing depth in the cell. The top layer is an oil phase enriched with solvent that can easily be recovered. However, the bottom layer mainly contains the heavy components, including asphaltene deposits, and is left behind in $\mathrm{HO}$ reservoirs.
5. As the mole fraction of the SM increases, the viscosity and density of the top layer gradually decrease. However, the viscosities and densities of the middle and bottom layers initially decrease, and then a slight increase is observed. Therefore, the in situ heavy oil upgrading significantly enhances the dissolution of SM in $\mathrm{HO}$ and reduces the viscosity and density of the HO.

6. The fundamental mechanisms associated with using the SM as a heavy oil recovery agent include driving the solution gas, reducing the viscosity and density, producing swelling effects, and upgrading the heavy oil in situ. The SM shows promising application potential for the enhancement of HO recovery in solvent-based processes.

Acknowledgements This work was financially supported by the National Natural Science Foundation of China (No. 51604293), the Shandong Provincial Natural Science Foundation, China (No. ZR2016EEB30), the Fundamental Research Funds for the Central Universities (No. 17CX02009A), the Qingdao Applied Basic Research Program (Source Innovation) (No. 17-1-1-32-jch), the Scientific Research Foundation of China University of Petroleum for Talent Introduction (No. YJ201601093), and the National Science and Technology Major Project (2016ZX05031-002).

Open Access This article is licensed under a Creative Commons Attribution 4.0 International License, which permits use, sharing, adaptation, distribution and reproduction in any medium or format, as long as you give appropriate credit to the original author(s) and the source, provide a link to the Creative Commons licence, and indicate if changes were made. The images or other third party material in this article are included in the article's Creative Commons licence, unless indicated otherwise in a credit line to the material. If material is not included in the article's Creative Commons licence and your intended use is not permitted by statutory regulation or exceeds the permitted use, you will need to obtain permission directly from the copyright holder. To view a copy of this licence, visit http://creativecommons.org/licenses/by/4.0/.

\section{Appendix: Correlations of heavy oil properties}

1. Critical temperature $\left(T_{\mathrm{c}}\right)$ (Kesler and Lee 1976; Li et al. 2013; Yang et al. 2014)

$$
\begin{aligned}
& T_{\mathrm{c}}=T_{\mathrm{cR}} / 1.8 \\
& T_{\mathrm{b}}=T_{\mathrm{bR}} / 1.8
\end{aligned}
$$




$$
\begin{aligned}
T_{\mathrm{cR}}= & 341.7+811 \gamma+(0.4244+0.1174 \gamma) T_{\mathrm{bR}} \\
& +(0.4669-3.2623 \gamma) \times 10^{5} T_{\mathrm{bR}}^{-1} \\
T_{\mathrm{bR}}= & 1928.3-\left(1.695 \times 10^{5}\right) M^{-0.03522} \gamma^{3.266} \\
& \times \exp \left[-\left(4.922 \times 10^{-3}\right) M-4.7685 \gamma+\left(3.462 \times 10^{-3}\right) M \gamma\right]
\end{aligned}
$$

where $T_{\mathrm{b}}$ and $T_{\mathrm{c}}$ are the normal boiling point at $101.32 \mathrm{kPa}$ and the critical temperature of $\mathrm{HO}$ in $\mathrm{K}$.

2. Critical pressure $\left(P_{\mathrm{c}}\right)$ (Kesler and Lee 1976; Li et al.

2013; Yang et al. 2014)

$$
P_{\mathrm{cR}}=\exp \left\{\begin{array}{c}
8.3634-0.0566 \gamma^{-1}-\left[\left(0.24244+2.2898 \gamma^{-1}+0.11857 \gamma^{-2}\right) \times 10^{-3}\right] T_{\mathrm{bR}} \\
+\left[\left(1.4685+3.648 \gamma^{-1}+0.47227 \gamma^{-2}\right) \times 10^{-7}\right] T_{\mathrm{bR}}^{2} \\
-\left[\left(0.42019+1.6977 \gamma^{-2}\right) \times 10^{-10}\right] T_{\mathrm{bR}}^{3}
\end{array}\right\}
$$

$P_{\mathrm{c}}=6.895 P_{\mathrm{cR}}$

where $P_{\mathrm{cR}}$ is the critical pressure in psia.

3. Acentric factor $(\omega)$ (Lee and Kesler 1975; Li et al. 2013;

Yang et al. 2014)

$$
\begin{gathered}
\text { If } T_{\mathrm{br}}=T_{\mathrm{bR}} / T_{\mathrm{cR}}<0.8 \\
\omega=\frac{-\ln \left(P_{\mathrm{cR}} / 14.7\right)-5.92714+6.09648 T_{\mathrm{br}}^{-1}+1.28862 \ln T_{\mathrm{br}}-0.169347 T_{\mathrm{br}}^{6}}{15.2518-15.6875 T_{\mathrm{br}}^{-1}-13.4721 \ln T_{\mathrm{br}}+0.43577 T_{\mathrm{br}}^{6}}
\end{gathered}
$$

$$
\begin{aligned}
& \text { If } T_{\mathrm{br}}=T_{\mathrm{bR}} / T_{\mathrm{cR}}>0.8 \\
& \begin{aligned}
\omega= & -7.904+0.1352 \frac{T_{\mathrm{b}}^{1 / 3}}{\gamma}-0.007465\left(\frac{T_{\mathrm{b}}^{1 / 3}}{\gamma}\right)^{2}+8.359 T_{\mathrm{br}} \\
& +\left(1.408-0.01063 \frac{T_{\mathrm{b}}^{1 / 3}}{\gamma}\right) T_{\mathrm{br}}^{-1}
\end{aligned}
\end{aligned}
$$

$T_{\mathrm{b}}=T_{\mathrm{bR}} / 1.8$

where $T_{\mathrm{b}}$ is the boiling point of $\mathrm{HO}$ at $101.32 \mathrm{kPa}$ in $\mathrm{K}$ and $T_{\mathrm{br}}$ is the reduced boiling point of $\mathrm{HO}$.

\section{References}

Abusahmin BS, Karri RR, Maini BB. Influence of fluid and operating parameters on the recovery factors and gas oil ratio in high viscous reservoirs under foamy solution gas drive. Fuel. 2017;197:497517. https://doi.org/10.1016/j.fuel.2017.02.037.

Ahadi A, Torabi F. Effect of light hydrocarbon solvents on the performance of $\mathrm{CO}_{2}$-based cyclic solvent injection (CSI) in heavy oil systems. J Pet Sci Eng. 2018;163:526-37. https://doi. org/10.1016/j.petrol.2017.12.062.
Ahmadi MA, Zendehboudi S, James LA. Hybrid connectionist model determines $\mathrm{CO}_{2}$-oil swelling factor. Pet Sci. 2018;15(3):591-604. https://doi.org/10.1007/s12182-018-0230-5.

Al-Gawfi A, Zirrahi M, Hassanzadeh H, et al. Development of generalized correlations for thermophysical properties of light hydrocarbon solvents $\left(\mathrm{C}_{1}-\mathrm{C}_{5}\right)$ /bitumen systems using genetic programming. ACS Omega. 2019;4(4):6955-67. https://doi.org/10.1021/ acsomega.9b00150.

Azinfar B, Haddadnia A, Zirrahi M, et al. A thermodynamic model to predict propane solubility in bitumen and heavy oil based on experimental fractionation and characterization. J Pet Sci Eng. 2018a;168:156-77. https://doi.org/10.1016/j.petrol.2018.04.065.

Azinfar B, Haddadnia A, Zirrahi M, et al. Phase behaviour of butane/ bitumen fractions: experimental and modeling studies. Fuel. 2018b;220:47-59. https://doi.org/10.1016/j.fuel.2018.02.008.

Badamchi-Zadeh A, Yarranton H, Svrcek W, et al. Phase behavior and physical property measurements for VAPEX solvents: part I. propane and athabasca bitumen. J Can Pet Technol. 2009;48(3):5765. https://doi.org/10.2118/09-01-54.

Chueh PL, Prausnitz JM. Vapor-liquid equilibria at high pressures: calculation of partial molar volumes in non-polar liquid mixtures. AIChE J. 1967;13(6):1099-107.

Dong ZX, Li Y, Lin M, et al. A study of the mechanism of enhancing oil recovery using supercritical carbon dioxide microemulsions. Pet Sci. 2013;10(1):91-6. https://doi.org/10.1007/s1218 2-013-0254-9.

Du ZW, Zeng FH, Peng XL, et al. Experimental and material balance equations analyses of cyclic solvent injection based on a large 3D 
physical model. Fuel. 2017;215:915-27. https://doi.org/10.1016/j. fuel.2017.10.076.

Du ZW, Zeng FH, Peng XL, et al. Optimizing the pressure decline rate on the cyclic solvent injection process for enhanced heavy oil recovery. J Pet Sci Eng. 2016;145:629-39. https://doi. org/10.1016/j.petrol.2016.06.028.

Frauenfeld TWJ, Kissel GA, Zhou WS. PVT and viscosity measurements for Lloydminster-Aberfeldy and cold lake blended oil systems. In: SPE international thermal operations and heavy oil symposium and international horizontal well technology conference, 4-7 November. Calgary, Alberta, Canada; 2002. https://doi. org/10.2118/2002-110.

Guan WL, Wu SH, Jian Z, et al. Utilizing natural gas huff and puff to enhance production in heavy oil reservoir. In: SPE international thermal operations and heavy oil symposium, 20-23 October. Calgary, Alberta, Canada; 2008. https://doi.org/10.2118/11733 5-MS.

Haddadnia A, Sadeghi Yamchi H, Zirrahi M, et al. New solubility and viscosity measurements for methane-, ethane-, propane-, and butane-Athabasca bitumen systems at high temperatures up to $260{ }^{\circ} \mathrm{C}$. J Chem Eng Data. 2018a;63(9):3566-71. https://doi. org/10.1021/acs.jced.8b00443.

Haddadnia A, Zirrahi M, Hassanzadeh $\mathrm{H}$, et al. Thermo-physical properties of $n$-pentane/bitumen and $n$-hexane/bitumen mixture systems. Can J Chem Eng. 2018b;96(1):339-51. https://doi. org/10.1002/cjee.22873.

Jhaveri BS, Youngren GK. Three-parameter modification of the PengRobinson equation of state to improve volumetric predictions. SPE Res Eng. 1988;3(3):1033-40. https://doi.org/10.2118/13118-PA.

Kariznovi M, Nourozieh H, Abedi J. Experimental apparatus for phase behavior study of solvent-bitumen systems: a critical review and design of a new apparatus. Fuel. 2011;90(2):536-46. https://doi. org/10.1016/j.fuel.2010.10.019.

Kesler MG, Lee BI. Improve predictions of enthalpy of fractions. Hydrocarbon Process. 1976;55:153.

Kordestany A, Hassanzadeh H, Abedi J. An experimental approach to investigating permeability reduction caused by solvent-induced asphaltene deposition in porous media. Can J Chem Eng. 2019;97(1):361-71. https://doi.org/10.1002/cjce.23238.

Lee BI, Kesler MG. A generalized thermodynamics correlation based on three-parameter corresponding states. AIChE J. 1975;21:510.

Li CJ, Jia WL, Wu X. Application of Lee-Kesler equation of state to calculating compressibility factors of high pressure condensate gas. Energy Procedia. 2012b;14(18):115-20. https://doi. org/10.1016/j.egypro.2011.12.904.

Li HZ, Yang DY. Modified $\alpha$ function for the Peng-Robinson equation of state to improve the vapor pressure prediction of non-hydrocarbon and hydrocarbon compounds. Energy Fuels. 2011;25(1):21523. https://doi.org/10.1021/ef100927z.

Li HZ, Yang DY. Phase behaviour of $\mathrm{C}_{3} \mathrm{H}_{8}-n-\mathrm{C}_{4} \mathrm{H}_{10}$-heavy oil systems at high pressures and elevated temperatures. J Can Pet Technol. 2013;52(1):30-40. https://doi.org/10.2118/157744-PA.

Li HZ, Zheng SX, Yang DY. Enhanced swelling effect and viscosity reduction of solvents- $\mathrm{CO}_{2}$ heavy oil systems. SPE J. 2011;18(4):695-707. https://doi.org/10.2118/150168-MS.

Li HZ, Yang DY, Tontiwachwuthikul P. Experimental and theoretical determination of equilibrium interfacial tension for the solvent(s)$\mathrm{CO}_{2}$-heavy oil systems. Energy Fuels. 2012a;26(3):1776-86. https ://doi.org/10.1021/ef201860f.

Li HZ, Yang DY, Li XL. Determination of three-phase boundaries of solvent (s)- $\mathrm{CO}_{2}$-heavy oil systems under reservoir conditions. Energy Fuels. 2012c;27(1):145-53. https://doi.org/10.1021/ef301 549a.

Li XL, Li HZ, Yang DY. Determination of multiphase boundaries and swelling factors of solvent(s)- $\mathrm{CO}_{2}$-heavy oil systems at high pressures and elevated temperatures. Energy Fuels. 2013;27(3):1293-306. https://doi.org/10.1021/ef301866e.

Liu PC, Mu ZB, Li WH, et al. A new mathematical model and experimental validation on foamy-oil flow in developing heavy oil reservoirs. Sci Rep. 2017;7:1-13. https://doi.org/10.1038/s4159 8-017-08882-2.

Liu RJ. Practice and application of non hydrocarbon gas recovery in interbedded super heavy oil. Unconventional Oil \& Gas. 2019;75(4):40-5 (in Chinese).

Luo P, Yang CD, Gu YG. Enhanced solvent dissolution into in situ upgraded heavy oil under different pressures. Fluid Phase Equilibri. 2007a;252(1-2):143-51. https://doi.org/10.1016/J.FLUID .2007.01.005.

Luo P, Yang C, Tharanivasan AK, et al. In situ upgrading of heavy oil in a solvent-based heavy oil recovery process. J Can Pet Technol. 2007b;46(9):37-43. https://doi.org/10.2118/07-09-03.

Luo $\mathrm{P}$, Zhang YP, Wang XQ, et al. Propane-enriched $\mathrm{CO}_{2}$ immiscible flooding for improved heavy oil recovery. Energy Fuels. 2012;26(4):2124-35. https://doi.org/10.1021/ef201653u.

Maini BB. Laboratory Evaluation of solution gas drive recovery factors in foamy heavy oil reservoirs. In: CSPG and petroleum society joint convention, digging deeper, finding a better bottom line, 14-18 June. Calgary, Alberta, Canada; 1999. https://doi.org/10.2118/99-44.

Moriyoshi T, Morishita Y, Inubushi H. Compressions of water + alcohol mixtures at $298.15 \mathrm{~K}$ and $1000 \mathrm{~atm}$. J Chem Thermodyn. 1977;9(6):577-86.

Nourozieh H, Mohammad K, Abedi J. Measurement and prediction of density for the mixture of Athabasca bitumen and pentane at temperatures up to 200 C. Energy Fuels. 2014;28(5):2874-85. https:// doi.org/10.1021/ef4022784.

Oellrich L, Plocker U, Prausnitz JM, et al. Equation of state methods for computing phase equilibria and enthalpies. Int Chem Eng. 1981;21(1):1-15.

Peneloux A, Rauzy E, Freze R. A consistent correction for RedlichKwong-Soave volumes. Fluid Phase Equilib. 1982;8(1):7-23.

Peng D, Robinson DB. A new two-constant equation of state. Ind Eng Chem Fundam. 1976;15(1):59-64.

Shokri AR, Babadagli T. Feasibility Assessment of heavy oil recovery by $\mathrm{CO}_{2}$ injection after cold production with sands: lab-to-field scale modeling considering non-equilibrium foamy oil behavior. Appl Energy. 2017;205:615-25. https://doi.org/10.1016/j.apene rgy.2017.08.029.

Soh Y, Shokri AR, Babadagli T. Optimization of methane use in cyclic solvent injection for heavy-oil recovery after primary production through experimental and numerical studies. Fuel. 2018;214:45770. https://doi.org/10.1016/j.fuel.2017.11.064.

Sun XF, Zhang YY, Cui GL, et al. Feasibility study of enhanced foamy oil recovery of the orinoco belt using natural gas. J Pet Sci Eng. 2014;122:94-107. https://doi.org/10.1016/j.petrol.2014.06.022.

Sun XF, Dong M, Zhang YY, et al. Enhanced heavy oil recovery in thin reservoirs using foamy oil-assisted methane huff- $n$-puff method. Fuel. 2015;159:962-73. https://doi.org/10.1016/J. FUEL.2015.07.056.

Sun XF, Zhang YY, Song ZY, et al. Study on equilibrium and nonequilibrium PVT behavior of foamy oil using experiments and PVT correlations. J Pet Sci Eng. 2017a;156:927-44. https://doi. org/10.1016/j.petrol.2017.06.041.

Sun XF, Zhang YY, Chen GP, et al. Application of nanoparticles in enhanced oil recovery: a critical review of recent progress. Energies. 2017b;10(3):345. https://doi.org/10.3390/en10030345.

Sun XF, Zhang YY, Wang SL, et al. Experimental study and new threedimensional kinetic modeling of foamy solution-gas drive processes. Sci Rep. 2018a;8:1-15. https://doi.org/10.1038/s41598-018-22669 $-\mathrm{Z}$.

Sun XF, Zhang YY, Chen GP, et al. Wettability of hybrid nanofluidtreated sandstone/heavy oil/brine systems: implications for enhanced 
heavy oil recovery potential. Energy Fuels. 2018b;32(11):11118-35. https://doi.org/10.1021/acs.energyfuels.8b01730.

Sun XF, Zhang YY, Gai ZY, et al. Comprehensive experimental study of the interfacial stability of foamy oil and identification of the characteristic responsible for foamy oil formation. Fuel. 2019a;238:514 25. https://doi.org/10.1016/j.fuel.2018.10.096.

Sun XF, Zhao H, Zhang YY, et al. An experimental study on the oilsoluble surfactant-assisted cyclic mixed solvent injection process for heavy oil recovery after primary production. Fuel. 2019b;254:115656. https://doi.org/10.1016/j.fuel.2019.115656.

Talbi K, Kaiser TMV, Maini BB. Experimental investigation of $\mathrm{CO}_{2}$-based VAPEX for recovery of heavy oils and bitumen. J Can Pet Technol. 2008;47(4):1-8. https://doi.org/10.2118/08-04-29.

Twu CH, Chan HS. Rigorously universal methodology of volume translation for cubic equation of state. Ind Eng Chem Res. 2009;48(12):5901-6. https://doi.org/10.1021/ie900222j.

Upreti SR, Lohi A, Kapadia RA, et al. Vapor extraction of heavy oil and bitumen: a review. Energy Fuels. 2007;21(3):1562-74. https://doi. org/10.1021/ef060341j.

Yamchi HS, Zirrahi M, Hassanzadeh H, et al. Effect of additives on liquid-liquid equilibrium properties of butane/bitumen systems with applications to solvent aided bitumen recovery processes. Chem Eng Res and Des. 2018;137:452-60. https://doi.org/10.1016/j.cherd .2018.08.007.

Yang P, Li HZ, Yang DY. Determination of saturation pressures and swelling factors of solvent(s)-heavy oil systems under reservoir conditions. Ind Eng Chem Res. 2014;53(5):1965-72. https://doi. org/10.1021/ie403477u.

You Q, Wen Q, Fang J, et al. Experimental study on lateral flooding for enhanced oil recovery in bottom-water reservoir with high water cut. J Pet Sci Eng. 2019;174:747-56. https://doi.org/10.1016/j.petro 1.2018.11.053.

Yu CC, Shen SK. Progress in studies of natural gas conversion in China. Pet Sci. 2008;5(1):67-72. https://doi.org/10.1007/s 1218 2-008-0011-7.

Zendehboudi S, Chatzis I, Mohsenipour AA, et al. Dimensional analysis and scale-up of immiscible two-phase flow displacement in fractured porous media under controlled gravity drainage. Energy Fuels. 2011;25(4):1731-50. https://doi.org/10.1021/ef101506n.

Zhang X, Che HC, Liu YS, et al. The feasibility of application of in situ combustion for ultra-viscous heavy oil post solvent extraction. Unconventional Oil \& Gas. 2019a;2:52-6 (in Chinese).

Zhang Y, Gao M, You Q, et al. Smart mobility control agent for enhanced oil recovery during $\mathrm{CO}_{2}$ flooding in ultra-low permeability reservoirs. Fuel. 2019b;241:442-50. https://doi.org/10.1016/j. fuel.2018.12.069.

Zhang YY, Sun XF, Duan XW, et al. Diffusion coefficients of natural gas in foamy oil systems under high pressures. Pet Sci. 2015;12(2):293303. https://doi.org/10.1007/s12182-015-0023-z.

Zhao Z, Shi Y, Yang D, et al. Quantification of gas exsolution of alkane solvents-CO2 mixture in heavy oil with consideration of individual interfacial resistance under nonequilibrium conditions. J Pet Sci Eng. 2019;180:1112-23. https://doi.org/10.1016/j.petrol.2019.05.058.

Zhou X, Zeng FH, Zhang LH, et al. Foamy oil flow in heavy oil-solvent systems tested by pressure depletion in a sandpack. Fuel. 2016;171:210-23. https://doi.org/10.1016/j.fuel.2015.12.070.

Zhou X, Yuan QW, Zeng FH, et al. Experimental study on foamy oil behavior using a heavy oil-methane system in the bulk phase. J Pet Sci Eng. 2017;158:309-21. https://doi.org/10.1016/j.petro 1.2017.07.070.

Zirrahi M, Hassanzadeh $\mathrm{H}$, Abedi J, et al. Prediction of solubility of $\mathrm{CH}_{4}, \mathrm{C}_{2} \mathrm{H}_{6}, \mathrm{CO}_{2}, \mathrm{~N}_{2}$ and $\mathrm{CO}$ in bitumen. Can J Chem Eng. 2014;92(3):563-72. https://doi.org/10.1002/cjce.21877.

Zirrahi M, Hassanzadeh H, Abedi J. Experimental and modeling studies of water, light $n$-alkanes and MacKay River bitumen ternary systems. Fuel. 2017a;196:1-12. https://doi.org/10.1016/j. fuel.2017.01.078.

Zirrahi M, Hassanzadeh H, Abedi J. Experimental and modelling studies of MacKay River bitumen and light $n$-alkane binaries. Can J Chem Eng. 2017b;95(7):1417-27. https://doi.org/10.1002/cjce.22775. 